\title{
Perencanaan Pengembangan Sumber Daya Teknologi Informasi dan Komunikasi dalam Mendukung Rencana Strategis di Sekolah Menengah
}

\author{
Angela Atik Setiyanti ${ }^{1}$, Dharmaputera T. Palekahelu², Eko Sediyono ${ }^{3}$ \\ Magister Sistem Informasi, Fakultas Teknologi Informasi, Universitas Kristen Satya Wacana \\ Jl. Diponegoro 52-60, Salatiga 50711 \\ E-mail: ${ }^{1}$ angela.setiyanti@staff.uksw.edu, ${ }^{2}$ dpalekahelu2@gmail.com, ${ }^{3}$ ekosed1@ yahoo.com
}

Masuk: 12 September 2015; Direvisi: 7 Oktober 2015; 18 Oktober 2015; Diterima: 19 Oktober 2015

\begin{abstract}
Information and Communication Technology (ICT) plays an important role in school activity processes. ICT requires adequate ICT infrastructure, the ability of teachers to use ICT, the school policy, maintenance, and the use of ICT in learning. However, the low level of ICT integration into school activity processes has not met the whole school's needs. Ward and Peppard method is used to develop ICT Resources Planning in this study for High School in Salatiga, Indonesia. The ICT Resources Planning is supporting the strategic planning to answer a variety of organizational needs based on the analysis of the school activity environment and ICT environment both internally and externally. This research results in a proposal or a recommendation on ICT Resources Planning blueprint document for school which provides alignment between the ICT and vision \& mission of the school.
\end{abstract}

Keywords: Resources Planning Development, Strategic Planning, Information and Communication Technology (ICT), Ward and Peppard.

\begin{abstract}
Abstrak. Teknologi Informasi dan Komunikasi (TIK) mempunyai peran yang sangat penting dalam proses aktivitas sekolah. Hal ini menuntut adanya infratruktur yang memadai, kemampuan guru untuk mengoperasikan TIK, kebijakan sekolah, perawatan, dan pemanfaatannya dalam pembelajaran. Namun rendahnya integrasi TIK dalam proses aktivitas sekolah saat ini belum dapat memenuhi kebutuhan sekolah secara menyeluruh. Metode Ward and Peppard digunakan dalam penelitian ini untuk membangun perencanaan pengembangan sumber daya TIK pada sekolah menengah di Salatiga, Indonesia. Perencanaan Pengembangan ini untuk mendukung Perencanaan Strategis TIK untuk menjawab berbagai kebutuhan organisasi sekolah berdasarkan analisis terhadap lingkungan aktivitas sekolah dan lingkungan TIK internal dan eksternal. Penelitian ini menghasilkan proposal atau usulan Perencanaan Pengembangan Sumber Daya TIK untuk sekolah yang dapat menyelaraskan TIK dengan visi dan misi sekolah. Kata kunci: Perencanaan Pengembangan Sumber Daya, Perencanaan Strategis Teknologi Informasi dan Komunikasi (TIK), Ward and Peppard.
\end{abstract}

\section{Pendahuluan}

Peran Teknologi Informasi dan Komunikasi (TIK) dalam pendidikan sesuai dengan blue print Kemendiknas mencakup empat hal, yaitu: (1) TIK sebagai gudang ilmu pengetahuan, (2) TIK sebagai alat bantu pembelajaran, (3) TIK sebagai fasilitas pendidikan, dan (4) TIK sebagai standar kompetensi. Sehingga dapat disimpulkan bahwa eksistensi TIK di sekolah dengan pemanfaatannya yang maksimum sangat penting diupayakan. Di dalam surat edaran resmi dari Kemendikbud no.19 tahun 2015 tertulis bahwa sekolah menengah di Jawa Tengah akan mengimplementasikan Ujian Nasional Online atau Computer Based Test (CBT), sehingga setiap sekolah harus menyiapkan infrastruktur seperti: komputer dan jaringan internet untuk mendukung kebijakan ini.

Saat ini masih terjadi hambatan dalam pemanfaatan TIK dalam pembelajaran di sekolah. Kurangnya kemampuan guru untuk menggunakan perangkat TIK karena tidak ada pelatihan dari sekolah maupun dinas pendidikan, kurangnya infrastruktur yang dimiliki sekolah dikarenakan beratnya beban financial yang harus ditanggung sekolah dalam hal pengadaan, 
pemeliharaan, dan pembaruan infrastruktur TIK (Sumintono, dkk., 2012). Dari permasalahan tersebut maka perlu dianalisis sumber daya apa saja yang sudah dimiliki oleh sekolah? Sejauh mana sumber daya tersebut berfungsi? Dengan melihat bagaimana ketersediaan dan kesiapan sumber daya tersebut maka dapat disusun kerangka kerja perencanaan sumber daya TIK dalam rangka menunjang penyusunan rencana strategis TIK di sekolah.

Metode Ward and Peppard digunakan dalam penyusunan perencanaan pengembangan sumber daya TIK di sekolah menengah di Kota Salatiga. Pendekatan ini merupakan metodologi untuk menghasilkan sebuah perencanaan strategis TIK yang mengkombinasikan berbagai alat analisis seperti SWOT dan Value Chain Activity (Ward, dkk., 2002), mampu menganalisis kesenjangan informasi antara kegiatan sekolah dan TIK yang digunakan serta dapat memberikan keunggulan kompetitif berdasarkan peluang yang dimiliki oleh sekolah. Sehingga hasil perencanaan sumberdaya TIK ini dapat mendukung perencanaan strategis TIK secara keseluruhan dalam menjawab berbagai kebutuhan organisasi berdasarkan analisis lingkungan bisnis dan lingkungan TIK baik lingkungan internal maupun lingkungan eksternal.

\section{Tinjauan Pustaka}

TIK didefinisikan ke dalam tiga kategori, yaitu: Information Technology (IT), Communication Technology (CT), dan Information Literacy. Termasuk di dalam IT adalah perangkat keras (komputer, printer, dll.) dan perangkat lunak (database, Microsoft Office, dll.) yang dapat digunakan untuk mengakses, mengambil, menyimpan, mengatur, memanipulasi, dan menyajikan informasi dari peralatan elektronik. CT merujuk pada peralatan telekomunikasi yang dapat digunakan untuk mencari dan mengakses informasi (telepon, faks, modem dengan komputer, dll.). Sedangkan Information Literacy adalah kombinasi dari pengetahuan, pemahaman, kemampuan, dan sikap yang diperlukan seseorang agar dapat bermanfaat bagi masyarakat luas. Orang yang sudah "melek technologi" dapat mengembangkan kemampuan untuk memilih, menginterprestasikan, menguji, memanipulasi, dan mempersembahkan informasi (Bangkok, 2003).

Butler dan Sebom (dalam Sumintomo, 2012) menyatakan bahwa ketersediaan fasilitas TIK di sekolah, seperti komputer, LCD, internet, dll., maupun kepemilikan komputer pribadi oleh guru merupakan hal utama yang sangat berpengaruh terhadap penggunaan TIK dalam pembelajaran. Fasilitas TIK yang kurang memadai adalah salah satu faktor utama dalam penghalang keefektifan pemanfaatan TIK dalam pembelajaran (Gülbahar, 2008). Faktor lain yang berpengaruh adalah kurangnya kesempatan pelatihan bagi guru dalam penggunaan TIK (Gülbahar, dkk., 2008). Tingkat kompetensi individu guru juga sangat berpengaruh dalam implementasi TIK dan persepsi motivasi siswa dan guru itu sendiri (Gobbo, dkk., 2001). Tingginya harga software dan hardware, lemahnya infrastruktur, kurangnya pengetahuan dan ketrampilan TIK, kurangnya software yang sesuai dan selaras dengan kultur, juga tingginya biaya internet merupakan faktor penghalang bagi pengintegrasian TIK di sekolah (AduwaOgiegbaen, dkk., 2005).

Meskipun dewasa ini TIK merupakan elemen yang sangat mutakhir dalam pembelajaran di kelas, namun banyak guru yang belum memanfaatkan jaringan elektronik untuk mengembangkan kegiatan pembelajaran meskipun sekolah mereka sudah menyediakan fasilitas yang sangat mendukung untuk hal tersebut (Carmichael, dkk., 2006). Bagaimana beragam dan canggihnya peralatan TIK menjadi tantangan bagi guru dalam hal memahami bagaimana menentukan penggunaan TIK yang sesuai dan efektif pada situasi tertentu dalam pembelajaran (Passey, 2006). Penggunaan TIK dalam pembelajaran bahasa sangat mendukung peningkatan kemampuan berbahasa siswa (Hussain, dkk., 2010).

Perencanaan pengembangan sumber daya TIK guna mendukung perencanaan strategis TIK di sekolah dapat disusun dengan menggunakan berbagai metodologi. Salah satunya adalah dengan pendekatan metodologi versi Ward and Peppard. Metodologi ini dimulai dari proses identifikasi kondisi investasi sumber daya TIK di masa lalu yang kurang bermanfaat bagi tujuan TIK dalam pendidikan dan menangkap peluang, serta fenomena guna meningkatkan keunggulan kompetitif sekolah karena mampu memanfaatkan sumber daya dengan maksimal (Ward, dkk. 
2002). Gambar 1 menunjukkan skema metodologi perencanaan strategis menurut Ward and Peppard.

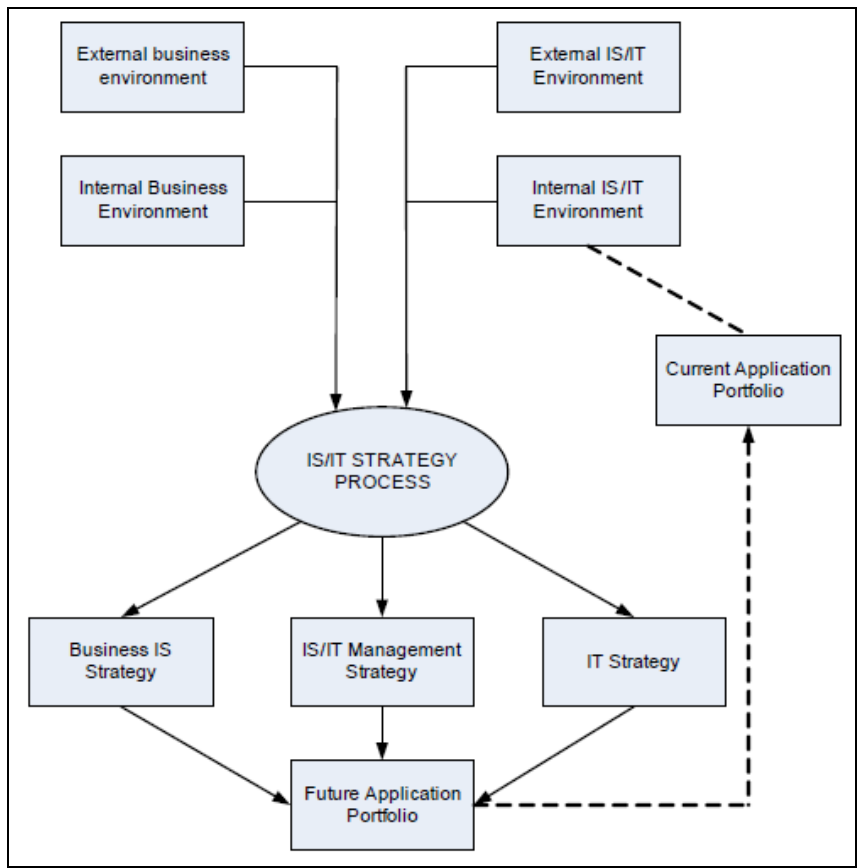

Gambar 1. Metodologi Perencanaan Strategis SI/TI (Ward, dkk., 2002)

Pendekatan perencanaan strategis yang dikemukkan oleh Ward, dkk. (2002) ini menjadi pilihan untuk penelitian ini karena metodologi ini mempunyai tiga sasaran utama yaitu: Pertama, memperbaiki efisiensi kerja dengan melakukan otomasi berbagai proses yang mengelola informasi; Kedua, meningkatkan efektifitas manajemen dengan memuaskan kebutuhan informasi untuk pengambilan keputusan; dan Ketiga, memperbaiki daya saing atau meningkatkan keunggulankompetitif organisasi dengan merubah gaya dan cara berbisnis (Ward, dkk., 2002). Pendekatan ini dapat diadaptasi untuk membuat perencanaan pengembangan sumber daya TIK guna menunjang perencanaan strategis TIK di sekolah. Beberapa alat analisis yang digunakan dalam penelitian ini yaitu antara lain: Benchmarking, SWOT, Porter's Value Chain Activityi, dan McFarlan's Strategic Grid Portofolio. Benchmarking digunakan untuk menganalisis kondisi bisnis eksternal dan kondisi TIK eksternal. Alat analisis SWOT digunakan dalam penelitian ini untuk menganalisis bisnis internal karena mampu menghasilkan berbagai strategi yang dapat dilakukan organisasi sesuai dengan tujuan bisnisnya. Value Chain Activity juga digunakan untuk menganalisis hal yang sama karena dapat memetakan selurus proses kerja atau aktivitas dalam organisasi tersebut ke dalam dua bagian yaitu; aktivitas utama dan aktivitas pendukung. Sedangkan McFarlan Strategis Grid untuk menganalisis kondisi TIK internal karena dapat memetakan data ke dalam empat bagian berdasarkan kontibusinya terhadap organisasi.

\section{Metodologi Penelitian}

Data diperoleh dari empat sekolah sampel dari keseluruhan 10 SMP Negeri di kota Salatiga yang menjadi populasi dalam penelitian ini. Pengambilan sampel menggunakan teknik Simple Random Sampling dimana sampel diambil secara acak karena anggota populasi dianggap homogen (Sugiyono, 2008), yaitu semua SMP Negeri. Pengolahan data dilakukan dengan pendekatan kuantitatif sederhana, yaitu dengan cara membuat tabulasi dan dihitung prosentasenya.Analisis data dilakukan dengan cara reduksi data, penyajian data, dan penarikan kesimpulan. Validitas data menggunakan teknik triangulasi, yaitu dengan membandingkan data dari sumber yang lain. Data angket yang dikumpulkan dibandingkan dengan data wawancara dan observasi. Dengan demikian dapat diketahui keadaan yang sebenarnya dari sekolah yang 
diteliti. Data angket diperoleh dari koordinator sarpras, guru, dan siswa, yang berupa angket kombinasi antara check list, angket terbuka, dan angket tertutup (Arikunto, 2006). Angket sarpras dan check list observasi digunakan untuk mengetahui ketersediaan fasilitas TIK. Angket siswa digunakan untuk mengetahui ketrampilan dan penggunaan TIK oleh siswa. Angket guru digunakan untuk mengetahui ketrampilan guru dan penggunaan TIK, perangkat TIK yang paling bermanfaat untuk menunjang pembelajaran, kesulitan, dan tanggapan guru terhadap penggunaan TIK dalam proses belajar mengajar. Wawancara kepada Kepala Sekolah dan kepala Dinas Pendidikan Pemuda dan Olahraga untuk mengetahui kebijakan sekolah berkaitan dengan TIK.

Tahapan penelitian akan berpedoman pada metodologi perencanaan strategis sistem informasi yang dikemukakan Ward dan Peppard. Tahapan penelitian yang dilakukan dalam penelitian ini adalah seperti pada Gambar 2.

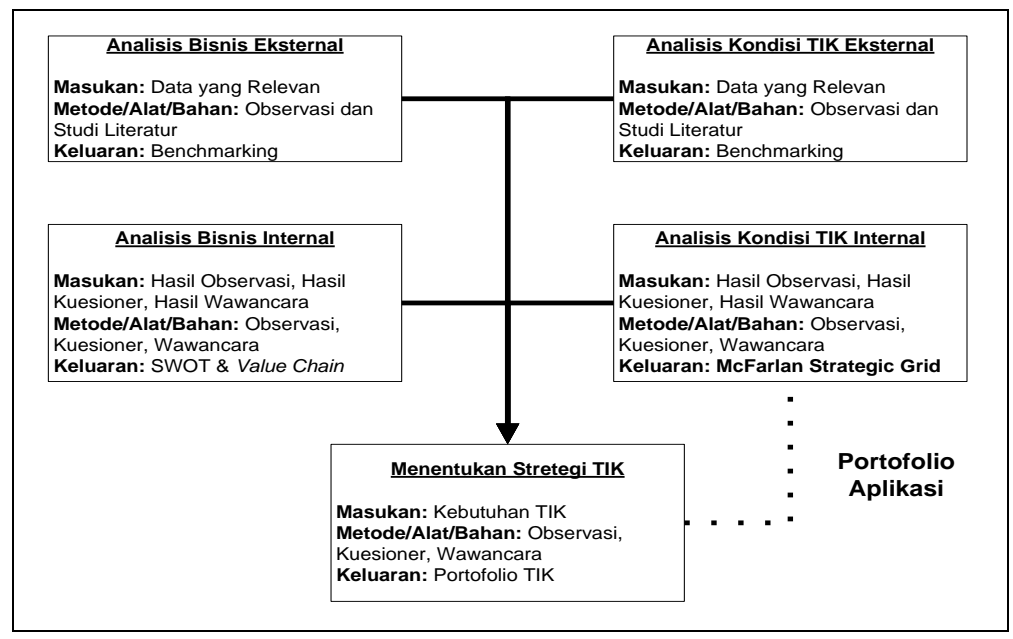

Gambar 2. Tahapan Penelitian

Berdasarkan tahapan penelitian pada Gambar 2, dilakukan analisis lingkungan bisnis dan lingkungan TIK secara eksternal dan internal di sekolah. Tahap 1 adalah melakukan analisis terhadap kondisi bisnis eksternal. Pada tahap ini akan dilakukan study literature mengenai kondisi ideal kegiatan dan ketrampilan guru, siswa, dan koordinator sarana prasarana TIK di sekolah. Hasil analisis digunakan sebagai Benchmarking. Tahap 2 yaitu melakukan analisis terhadap kondisi TIK eksternal. Pada tahap ini akan dilakukan study literature mengenai kondisi ideal sarana dan prasarana TIK di sekolah. Alat analisis yang digunakan yaitu Benchmarking.

Tahap 3 adalah melakukan analisis terhadap kondisi bisnis internal. Pada tahap ini akan dilakukan wawancara, angket, dan analisis terhadap kegiatan guru, siswa, dan koordinator TIK. Alat analisis yang digunakan yaitu Porter's Value Chain Activity dan SWOT. Tahap 4 yaitu melakukan analisis terhadap kondisi TIK internal. Pada tahap ini akan dilakukan observasi, wawancara, dan angket untuk mengetahui ketersediaan sarana dan prasarana di sekolah sehingga didapatkan daftar rencana pengembangan sumber daya TIK. Alat analisis yang digunakan yaitu McFarlan's Strategic Grid Portofolio. Tahap 5 menentukan kerangka kerja perencanaan pengembangan sumber daya TIK. Pada tahap ini akan dibuat kerangka kerja dengan memperhatikan hasil wawancara dan pengolahan data hasil angket, dibandingkan dengan kondisi ideal yang ada sehingga akan diambil kebijakan terhadap rencana pengembangan sumber daya TIK di sekolah.

\section{Analisis dan Perencanaan Strategis}

\subsection{Analisis Kondisi Bisnis Eksternal danAnalisis Kondisi TIK Eksternal}

Pengintegrasian TIK dalam pendidikan menurut UNESCO dibagi dalam empat tahap, yaitu emerging, applying, infusing dan transforming. Ilustrasi tahapan ini tampak pada Gambar 3. 


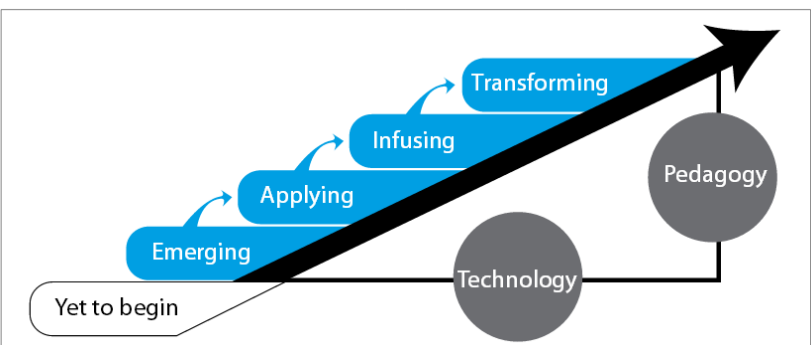

\section{Gambar 3. Tahapan Integrasi TIK dalam Pendidikan Menurut UNESCO}

UNESCO menetapkan juga beberapa karakteristik pengintegrasian TIK di sekolah, mulai dari administrasi sekolah hingga proses belajar mengajar. Karakteristik pengintegrasian TIK tersebut dapat dilihat dari segi visi, pedagogi, perencanaan dan kebijakan, fasilitas dan sumber daya, kurikulum, pengembangan kemampuan staff, komunitas serta penilaian. Dalam penelitian ini hanya membahas TIK pengembangan sumber daya, dalam hal ini fasilitas, pengajar, dan staff. Karakteristik yang digunakan dalam penelitian dapat dilihat pada Tabel 1.

Tabel 1. Karakteristik Tahapan Integrasi TIK dalam Penelitian

\begin{tabular}{|c|c|c|c|c|}
\hline & Emerging & Applying & Infusing & Transforming \\
\hline $\begin{array}{l}\text { Fasilitas dan } \\
\text { Sumber Daya }\end{array}$ & $\begin{array}{l}\text { Perangkat } r \text { TIK } \\
\text { berdiri sendiri } \\
\text { untuk } \\
\text { administrasi. } \\
\text { Komputer dan } \\
\text { printer. Aplikasi } \\
\text { pengolah kata, } \\
\text { angka, presentasi. } \\
\text { Aplikasi } \\
\text { administrasi } \\
\text { sekolah. Games }\end{array}$ & $\begin{array}{l}\text { Lab komputer dan } \\
\text { perngkat TIK di } \\
\text { kelas-kelas. } \\
\text { Komputer, printer } \\
\text { dan perangkat lain } \\
\text { yang terbatas. } \\
\text { Aplikasi pengolah } \\
\text { kata, angka, } \\
\text { presentasi. } \\
\text { Software TIK. } \\
\text { Akses internet }\end{array}$ & $\begin{array}{l}\text { Lab komputer atau } \\
\text { komputer di kelas. } \\
\text { Jaringan internet di } \\
\text { kelas. Intranet, internet. } \\
\text { Pusat belajar. berbagai } \\
\text { perangkat, termasuk } \\
\text { camdig, scanner, laptop, } \\
\text { dll. Aplikasi pengolah } \\
\text { kata, angka, presentasi. } \\
\text { Multimedia. Software } \\
\text { pembelajaran }\end{array}$ & $\begin{array}{l}\text { Seluruh pembelajaran menggunakan } \\
\text { TIK dengan akses ke seluruh } \\
\text { perangkat TIK. Memperhatikan } \\
\text { macam-macam lingkungan belajar. } \\
\text { pembelajaran berbasis web. } \\
\text { Pengungkapan pendapat. } \\
\text { Kolaborasi. Pembelajaran jarak } \\
\text { jauh. }\end{array}$ \\
\hline $\begin{array}{l}\text { Pengembangan } \\
\text { Kemampuan } \\
\text { staff }\end{array}$ & $\begin{array}{l}\text { Ketertarikan } \\
\text { individu }\end{array}$ & $\begin{array}{lr}\text { Pelatihan } & \text { TIK. } \\
\text { Tak direncanakan. } \\
\text { Kemampuan } \\
\text { pribadi }\end{array}$ & $\begin{array}{l}\text { Sesuai bidang studi. } \\
\text { Kemampuan profesional. } \\
\text { Mengintegrasi TIK ke } \\
\text { bidang studi. } \\
\text { Mengembangkan }\end{array}$ & $\begin{array}{l}\text { Fokus pada pembelajaran dan } \\
\text { manajemen pembelajaran. Diatur } \\
\text { diri sendiri, rencana dan visi } \\
\text { pribadi, didukung sekolah. inovatif, } \\
\text { kreatif. Komunitas pembelajaran } \\
\text { terintegrasi dengan siswa dan guru } \\
\text { sebagai asisten. }\end{array}$ \\
\hline
\end{tabular}

Karakteristik tahapan pengintegrasian TIK digunakan sebagai benchmark kondisi sumber daya TIK ideal di suatu sekolah dengan melihat karakteristik yang ada pada tahap transforming. Berkaitan dengan penelitian ini, Siahaan (2009) dalam Modul Pelatihan Pengembangan Dan Pemanfaatan Konten Jardiknas, DEPDIKNAS mengatakan di dalam blue print TIK untuk pendidikan, fungsi-fungsi TIK digambarkan sebagai sebuah bangunan gedung. Terdiri dari pondasi, tiang, dan atap, sebagaimana dapat dilihat pada Gambar 4.

Pertama, TIK berfungsi sebagai gudang ilmu pengetahuan, dapat berupa referensi berbagai ilmu pengetahuan yang tersedia dan dapat diakses melalui fasilitas TIK, pengelolaan pengetahuan, jaringan pakar, jaringan antara institusi pendidikan, pusat pengembangan materi ajar, wahana pengembangan kurikulum, dan komunitas perbandingan standar. Kedua, fungsi TIK sebagai alat bantu pembelajaran dapat berupa alat bantu mengajar bagi guru (animasi peristiwa, alat uji siswa, sumber referensi ajar, evaluasi kerja siswa), alat bantu belajar bagi siswa (buku interaktif, belajar mandiri, latihan soal, media ilustrasi), serta alat bantu interaksi antara guru dengan siswa (komunikasi guru-siswa, simulasi kasus, alat peraga visual, komunikasi antar guru, kolaborasi kelompok studi, manajemen kelas terpadu. Ketiga, fungsi TIK sebagai fasilitas pendidikan di sekolah dapat berupa pojok internet, perpustakaan digital, kelas virtual, lab multimedia, papan elektronik, intranet sekolah, kelas teater multimedia, kelas jarak jauh. Blue print TIK ini juga digunakan bersama-sama dengan Tahapan pengintegrasian TIK menurut UNESCO tadi sebagai benchmark dari penelitian ini. 


\section{PERANAN TIK DI SEKOLAH MODEREN}

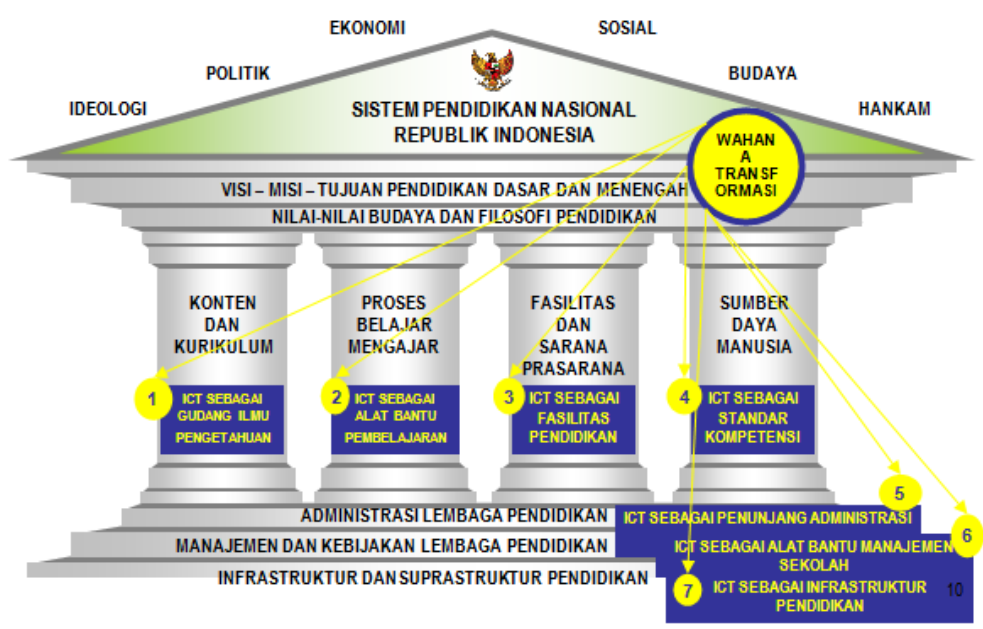

Gambar 4. Peranan TIK di Sekolah Modern (Siahaan, 2009)

\subsection{Analisis Kondisi Bisnis Internal}

Proses analisis ini adalah dengan melakukan metode wawancara dan kuesioner terhadap berbagai unit bisnis di sekolah. Alat analisis yang digunakan yaitu Value Chain. Analisis Value Chain dilakukan untuk menggambarkan aktivitas proses bisnis utama dan proses bisnis pendukung dari suatu organisasi. Analisis ini juga bertujuan untuk mengidentifikasi dan mengelompokkan kondisi aktivitas sumber daya TIK yang ada di sekolah ke dalam dua bagian besar yaitu aktivitas utama dan aktivitas pendukung. Hasil analisis ini kemudian akan digunakan untuk mengidentifikasi kebutuhan. Hasil anasila dengan Value Chain dapat digambarkan seperti pada Gambar 5.

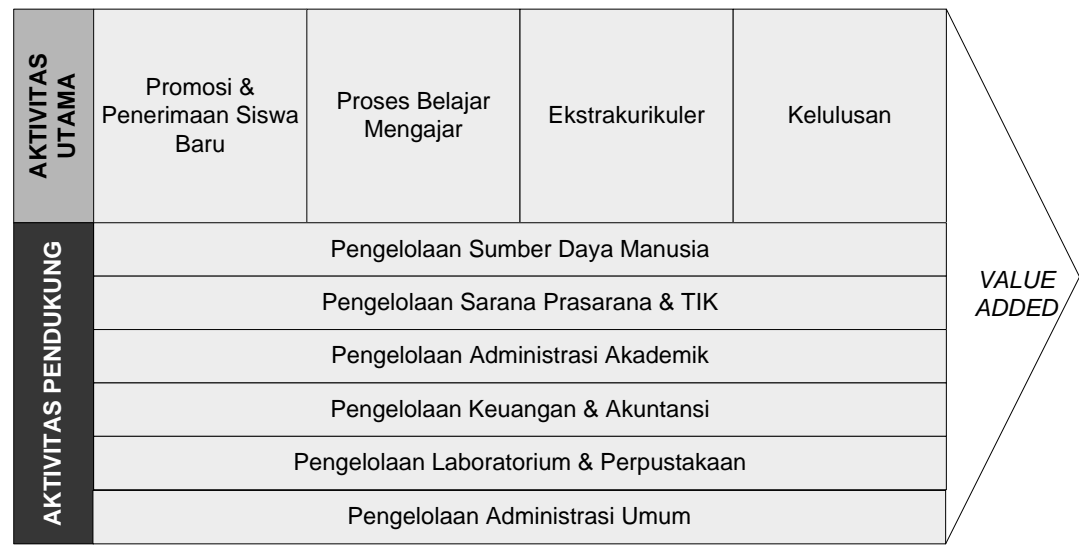

Gambar 5. Value Chain analisis lingkungan bisnis internal sekolah.

Pada Gambar 3 proses bisnis yang terdapat di sekolah menengah di Kota Salatiga diuraikan secara detail dalam bentuk aktivitas utama dan aktivitas pendukung, dimana masingmasing aktivitas membutuhkan TIK untuk menjalankannya. Setiap aktivitas melekat pada setiap unit yang ada di sekolah. Aktivitas utama adalah semua kegiatan yang dijalankan dalam mencapai tujuan sekolah, yaitu: aktivitas Promosi dan Penerimaan Siswa Baru, Proses Belajar Mengajar, Ekstrakurikuler, dan Kelulusan. Sedangkan untuk aktivitas pendukung adalah segala kegiatan yang merupakan pendukung aktivitas utama, yaitu: Pengelolaan Sumber Daya Manusia, Pengelolaan Sarana Prasarana dan TIK, Pengelolaan Administrasi Akademik, Pengelolaan Keuangan dan Akuntansi, Pengelolaan Laboratorium dan Perpustakaan, dan 
Pengelolaan Administrasi Umum. Setiap aktivitas, baik aktivitas utama maupun pendukung membutuhkan TIK dalam implementasinya untuk menjamin berjalannya proses bisnis di sekolah secara baik.

Analisis lingkungan bisnis internal yang diperoleh dari hasil wawancara dan pengamatan terhadap sekolah yang menjadi objek studi kasus menghasilkan beberapa informasi mengenai kondisi proses bisnis yang terdapat di sekolah yaitu antara lain: (1) PBM sebagai salah satu aktivitas utama sekolah harus mendapat perhatian utama. Dari penelitian diperoleh data bahwa masih ada guru yang belum menggunakan TIK dalam PBM yaitu sejumlah $24 \%$. Dari data tersebut diketahui bahwa alasan belum menggunakan TIK dikarenakan kurang memiliki ketrampilan dalam mengoperasikan perangkat TIK. (2) Pengelolaan Sarana Prasarana dan TIK di sekolah adalah masuk dalam kategori aktivitas pendukung dalam proses bisnis sekolah, namun demikian kondisi sarana prasarana TIK sangat penting bagi aktivitas utama PBM. Sarana dan prasarana TIK yang mendukung PBM diidentifikasi dalam penelitian ini yaitu hardware, software, dan internet.

Tahap selanjutnya adalah analisis kondisi TIK internal dengan menggunakan alat analisis SWOT untuk mengetahui kekuatan, kelemahan, peluang, dan ancaman organisasi. Hasil dari analisis tersebut dapat dilihat pada Tabel 2. Berdasarkan hasil analisis SWOT tersebut, maka dapat dirumuskan rumusan strategis pada Tabel 3.

Tabel 2. Analisis kondisi TIK internal dengan menggunakan alat analisis SWOT untuk mengetahui kekuatan, kelemahan, peluang, dan ancaman organisasi

\begin{tabular}{ll}
\hline \multicolumn{1}{c}{ SWOT } & \multicolumn{1}{c}{ Hasil Analisis } \\
\hline Kekuatan & Tersedianya sarana dan prasarana untuk mendukung proses belajar mengajar (PBM) seperti gedung sekolah, \\
(Strengths) & $\begin{array}{l}\text { laboratorium komputer. Kondisi sekolah A dan B dengan rasio pengguna komputer 1:15, LCD proyektor di } \\
\text { setiap ruang kelas, layanan internet untuk seluruh warga sekolah dimana wifi dipasang diberbagai sudut sekolah. }\end{array}$ \\
\hline $\begin{array}{l}\text { Kelemahan } \\
\text { (Weakness) }\end{array}$ & $\begin{array}{l}\text { Kondisi sekolah C dan D dengan rasio pengguna komputer 1:33, tidak semua kelas tersedia LCD proyektor, } \\
\text { kondisi LCD yang tidak memadai karena terdapat kerusakan pada lensa dan lensa, layanan internet yang terbatas } \\
\text { untuk guru dan karyawan saja sebagai penunjang tugas administrasi. Kurangnya pemanfaatan TIK dalam } \\
\text { pembelajaran dikarenakan kurang memiliki ketrampilan di dalam mengoperasikan perangkat TIK. }\end{array}$ \\
\hline $\begin{array}{l}\text { Peluang } \\
\text { (Opportunities) }\end{array}$ & $\begin{array}{l}\text { Bantuan dari pemerintah seperti JARDIKNAS yang akan diaktifkan lagi dimana sekolah dapat memanfaatkan } \\
\text { jaringan ini sebagai sistem informasi sekolah terpadu, biaya internet yang semakin terjangkau, dan masyarakat }\end{array}$ \\
& $\begin{array}{l}\text { yang semakin melek teknologi seharusnya dapat menjadi peluang yang bagus bagi perkembangan TIK di } \\
\text { sekolah. }\end{array}$ \\
\hline $\begin{array}{l}\text { Ancaman } \\
\text { (Threats })\end{array}$ & Meningkatnya persaingan antar sekolah dalam penerimaan siswa baru (data terlampir). \\
\hline
\end{tabular}

Tabel 3. Rumusan Strategi SWOT

Mengembangkan kekuatan dan mengoptimalkan peluang (S-O) Laboratorium komputer dan sarana TIK lainnya yang tersedia di sekolah dirawat dan dimanfaatkan secara maksimal dengan mengoptimalkan peluang yang ada bagi pengembangan TIK dalam pemanfaatannya sebagai sistem informasi sekolah. Peluang bantuan dari pemerintah seperti JARDIKNAS, peluang semakin terjangkaunya biaya internet, dan masyarakat (dalam hal ini siswa, guru, staff sekolah, dan orangtua siswa) yang semakin melek teknologi sangat mendukung bagi pengembangan pemanfaatan TIK di sekolah. Aplikasi SI pembelajaran online (e-learning) dipergunakan dalam proses belajar mengajar. Bahkan SI terpadu dapat diterapkan di sekolah

Meminimalkan kelemahan untuk memanfaatkan peluang (W-O) Meningkatkan kompetensi SDM melalui training, rekruitmen guru dengan keahlian di bidang TIK, dan melakukan kerjasama dengan instansi terkait untuk meningkatkan kinerja, sarana, dan prasarana.

\subsection{Analisis Kondisi TIK Internal}

Data yang diperoleh wawancara dan angket dipetakan sesuai fungsinya masing-masing menggunakan matriks Mc Farlan's Strategic Grid guna mengetahui prioritas pengembangan sumber daya yang akan diterapkan di sekolah. Pemetaan dilakukan pada empat kuadran yaitu:
Mengembangkan kekuatan untuk mengatasi ancaman (S-T) Dalam menghadapi persaingan penerimaan siswa baru, sekolah harus dapat memanfaatkan sarana dan prasarana yang ada semaksimal mungkin guna meningkatkan kualitas pendidikan.
Meminimalkan kelemahan dan menghindari ancaman (W-T) Bekerjasama dengan instansi atau sekolah lain dalam melakukan sharing pengetahuan terkait dengan perkembangan penerapan TIK, menjalin kerjasama dengan instansi pemerintah maupun instansi lain dalam melakukan penggalian SDM potensial, dan bekerja sama dengan instansi terkait dalam pengadaan program beasiswa bagi guru maupun siswa berprestasi atau kurang mampu. 
strategic, high potential, key operation, dan support (Ward, dkk., 2002). Dari hasil pemetaan yang dapat dilihat pada Gambar 6 maka diperoleh portofolio Perencanaan Pengembangan Sumber Daya TIK.

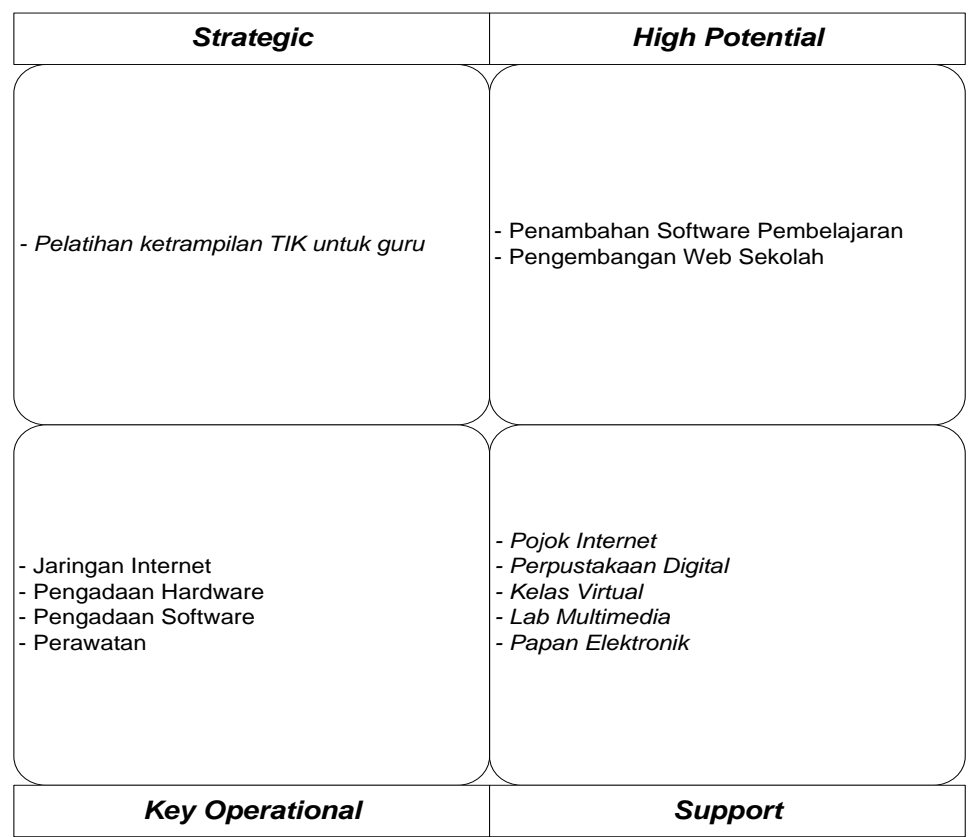

Gambar 6. McFarlan's Strategic Grid Portofolio Usulan Perencanaan Pengembangan Sumber Daya TIK

Pada kolom Strategic sumber daya yang memiliki pengaruh yang tinggi terhadap keberlangsungan dan perkembangan proses bisnis di sekolah yaitu ketrampilan TIK guru. Pelatihan untuk meningkatkan ketrampilan TIK guru akan sangat menunjang pemberdayaan fasilatas yang tersedia dan dapat meningkatkan kualitas PBM. Kolom Key Operational, yaitu sumber daya yang digunakan untuk kegiatan operasional sekolah, antara lain: jaringan internet, pengadaan hardware, pengadaan software dan perawatan. Dengan adanya ketiga hal tersebut akan sangat menunjang terwujudnya TIK sebagai alat bantu pembelajaran, yaitu sebagai alat bantu mengajar bagi guru, alat bantu belajar bagi siswa, dan alat bantu interaksi antara guru dan siswa. Kolom Support berisi sumberdaya yang sifatnya mendukung kolom Key Operational yaitu fasilitas pendidikan di sekolah yang berupa: pojok internet, perpustakaan digital, kelas virtual, lab multimedia, papan elektronik, dll. Sedangkan pada kolom High Potential yaitu sumber daya yang bersifat inovasi dan merupakan penggunaan teknologi baru yang dapat dikembangkan seperti penambahan software untuk pembelajaran dan pengembangan website sekolah untuk meningkatkan eksitensi sekolah.

\subsection{Diskusi}

Benchmarking yang dilakukan dengan mempelajari Tahapan Integrasi TIK dalam Pendidikan menurut UNESCO dapat diketahui bahwa kondisi ideal adalah seperti yang tertera pada Karakteristik Tahapan Intergrasi TIK kolom Transforming. Sedangkan hasil dari penelitian diketahui bahwa sekolah A dan B berada pada tahap Infusing, dan sekolah C dan D masih pada tahap Applying. Pada benchmarking dengan mempelajari Peranan TIK di Sekolah Modern (Siahaan, 2009) maka dapat disimpulkan TIK di sekolah sangat dibutuhkan.

Analisis lingkungan bisnis internal dengan menggunakan value chain memperlihatkan bahwa Proses Belajar Mengajar (PBM) ada pada Aktivitas Utama sekolah, sehingga ketersediaan dan pemanfaatan TIK guna menunjang PBM harus diprioritaskan. Analisis menggunakan SWOT dapat memberikan gambaran tentang sumber daya TIK yang mana yang perlu diberikan prioritas utama dan selanjutnya. Sedangkan pemetaan dengan menggunakan 
McFarlan's Strategic Grid dapat dengan jelas memberi gambaran jenis sumber daya TIK yang menjadi kunci utama proses bisnis organisasi, strategis, berpotensi tinggi, dan yang sifatnya hanya mendukung. Berdasarkan analisis dari alat-alat tersebut, maka dapatlah diusulkan tahap perencanaan pengembangan sumber daya TIK seperti pada Tabel 4.

Tabel 4. Rencana Pengembangan Sumber Daya TIK

\begin{tabular}{|c|c|c|c|c|}
\hline Pengembangan Sumber Daya & Tahap 1 & Tahap 2 & Tahap 3 & Tahap 4 \\
\hline Jaringan Internet & \multirow{4}{*}{$\begin{array}{l}\text { Key } \\
\text { Operational }\end{array}$} & & & \\
\hline Pengadaan Hardware & & & & \\
\hline Pengadaan Software & & & & \\
\hline \multicolumn{4}{|l|}{ Perawatan } & \\
\hline Pelatihan Keterampilan TIK untuk Guru & & Strategic & & \\
\hline Penambahan Software Pembelajaran & & & \multirow{2}{*}{$\begin{array}{l}\text { High } \\
\text { Potential }\end{array}$} & \\
\hline Pengembangan Web Sekolah & & & & \\
\hline Pojok Internet & & & & \multirow{5}{*}{ Support } \\
\hline Perpustakaan Digital & & & & \\
\hline Kelas Virtual & & & & \\
\hline Lab Multimedia & & & & \\
\hline Papan Elektronik & & & & \\
\hline
\end{tabular}

Usulan tahapan perencanaan pengembangan TIK di atas dapat bermanfaat bagi guru, siswa, sekolah, maupun Dinas Pendidikan. Beberapa manfaat TIK bagi guru melalui rencana pengembangan sumber daya yang diusulkan tersebut antara lain: (1) mendukung penggunaan kurikulum berbasis kompetensi yang telah diatur oleh Pemerintah, (2) meningkatkan penggunaan sumber daya pembelajaran di dalam kelas menjadi lebih sering dan lebih efektif, (3) meningkatkan pengetahuan, (4) meningkatkan konektivitas komunikasi dengan rekan guru baik di dalam sekolah atau di sekolah lain (misalnya: aplikasi mailing list guru), dan (5) mengembangkan peningkatan profesionalisme.

Manfaat bagi siswa, antara lain: (1) meningkatkan antusiasme dan motivasi siswa dalam belajar, (2) meningkatkan penggunaan sumber daya pembelajaran dan membangun pemahaman terhadap mata pelajaran yang diajarkan, (3) membangun kreativitas dan ketrampilan penggunaan TIK, dan (4) dapat melakukan kolaborasi belajar dengan siswa lain baik di sekolah maupun dengan sekolah lain. Sedangkan manfaat TIK bagi Dinas Pendidikan, antara lain: (1) meningkatkan partisipasi dalam pengembangan profesi guru, (2) meningkatkan kinerja, dan (3) meningkatkan penerimaan informasi yang lebih akurat dan lebih tepat tentang kondisi dan kegiatan-kegiatan yang diadakan di sekolah.

Berdasarkan hasil penelitian di atas, maka usulan rencana pengembangan sumber daya TIK di sekolah dapat menjadi bagian penting dalam Pengembangan Strategis TIK untuk pendidikan secara keseluruhan.

\section{Kesimpulan}

Hasil analisis yang diperoleh dalam penelitian ini dengan menggunakan Blue Print TIK dan Tahapan Pengintegrasian TIK menurut UNESCO sebagai benchmark, Value Chain Activity dan SWOT sebagai alat analisis lingkungan bisnis internal, dan McFarlan's Strategic Grid sebagai alat analisis lingkungan TIK internal menunjukkan bahwa sumber daya yang ada di sekolah menengah pertama di Salatiga belum dapat mendukung proses bisnis sekolah secara ideal. Dari hasil analisis tersebut dapatlah disusun kerangka kerja rencana pengembangan sumber daya TIK sekolah. Hal ini adalah untuk memberikan panduan dalam pembangunan renstra TIK untuk membantu meningkatkan kualitas pendidikan dengan mewujudkan sekolah yang sesuai dengan Blue Print TIK dan mencapai tahap transforming dalam Tahapan Pengintegrasian TIK menurut UNESCO. Penerapan metodologi Ward and Peppard dalam penyusunannya memberikan keselarasan antara TIK dengan visi, misi, dan tujuan sekolah karena portofolio usulan rencana pengembangan sumber daya TIK disusun berdasarkan hasil kajian dan analisis terhadap aktivitas utama dan aktivitas pendukung dimana perencanaan yang disusun berdasarkan skala prioritas kondisi setiap sekolah yang diteliti. Perubahan ketersediaan dan kebutuhan sumber daya TIK yang dapat berubah setiap waktu menyarankan dilakukannya 
evaluasi secara berkala. Hal ini untuk menentukan strategi yang harus diambil dalam jangka waktu tertentu guna menyelaraskan pengembangan sumber daya TIK dengan kebutuhan sekolah.

\section{Referensi}

Aduwa-Ogiegbaen, S.E., \& Iyamu, E. O. S. 2005. Using Information and Communication Technology in Secondary Schools in Nigeria: Problems and Prospects. Journal of Educational Technology \& Society, 8(1), pp. 104-112.

Bangkok, U. N. E. S. C. O. 2003. Developing and Using Indicators of ICT Use in Education. Compiled by UNESCO Asia and Pacific Regional Bureau for Education, Bangkok, and Southeast Asian Ministers of Education Organization Organization Regional Centre for Educational Innovation and Technology, Metro Manila, Philippines. (Online), (http://unesdoc.unesco.org/images/0013/001311/131124e.pdf, diakses 4 Juni 2015).

Carmichael, P., \& Procter, R. 2006. Are We There Yet? Teachers, Schools, and Electronic Networks. The Curriculum Journal, 17(2), pp. $167-186$.

Gobbo, C., \& Girardi, M. 2001. Teachers' Beliefs and Integration of Information and Communications Technology in Italian Schools, Journal of Information Technology for Teacher Education, 10(1-2), pp. 63-85.

Gülbahar, Y. 2008. ICT Usage in Higher Education: A Case Study on Preservice Teachers and Instructors, Turkish: The Turkish Online Journal of Educational Technology, 7(1), Article 3.

Gülbahar, Y., Guven, I., 2008, A Survey on ICT Usage and the Perceptions of Social Studies Teachers in Turkey, Educational Technology \& Society, 11 (3), 37-51.

Hussain, M. A., Niwaz, A., Zaman, A., Dahar, M. A., \& Akhtar, M. 2010. Technology Based Learning Environment and student Achievement in English as A Foreign Language in Pakistan. Journal of World Academic of Science, Engineering, and Technology, 2(5), pp. 129-133.

Passey, D. 2006. Technology Enhancing Learning: Analysing Uses of Information and Communication Technologies by Primary and Secondary School Pupils with Learning Frameworks. The Curriculum Journal, 17(2), pp. 139-166.

Siahaan, S. 2009. Modul Pelatihan Pengembangan Dan Pemanfaatan Konten Jardiknas, DEPDIKNAS.

Sumintono, B., Wibowo, S. A., Mislan, N., \& Tiawa, D. H. 2012. Penggunaan Teknologi Informasi dan Komunikasi dalam Pengajaran: Survei pada Guru-guru Sains SMP di Indonesia. Jurnal Pengajaran MIPA, 17(1), pp. 122-131.

Ward, J., Griffiths, P. M., \& Whitmore, P. 2002. Strategic Planning for Information Systems $3^{\text {rd }}$ Ed., XXVIII, UK: John Wiley \& Sons, Ltd. 